\title{
POLYGYNY AND POLYDOMY IN THREE NORTH \\ AMERICAN SPECIES OF THE ANT GENUS \\ LEPTOTHORAX MAYR (HYMENOPTERA: FORMICIDAE) ${ }^{1}$
}

BY

\author{
Thomas M. Alloway, ${ }^{2}$ Alfred Buschinger, ${ }^{3}$ Mary Talbot,${ }^{4}$ \\ Robin Stuart, ${ }^{2}$ and Cynthia ThOMAs ${ }^{2}$
}

\section{GENERAL INTRODUCTION}

This paper deals with certain behavioral and ecological factors which may be relevant to the evolution and maintenance of social parasitism in ants. We will argue that some of the same factors which might predispose one species to evolve into a social parasite might make resistance to parasitism difficult for a closely related species.

After their mating flight, the queens of most nonparasitic ant species found new colonies alone. A queen of such a species finds a suitable nesting place, excavates a small cavity, and seals herself inside. She then lays a clutch of eggs and feeds her first larvae a special "baby food" derived metabolically from the degeneration of her wing muscles and fat body. These larvae mature to become female workers which forage for food, enlarge the nest, feed the queen, and rear subsequent broods of workers and reproductives. Mature ant colonies usually occupy only one nest (monodomy). However, the number of queens in typical mature colonies varies. Colonies of some species never contain more than one functional queen (monogyny), while colonies of other species often have multiple queens (polygyny) (Buschinger 1974).

However, the queens of all known obligatory slave-making, inquiline, and temporary-parasite species found colonies non-inde-

1. This research was supported by grants to Thomas Alloway from the Natural Sciences and Engineering Research Council of Canada and to Alfred Buschinger from the Deutsche Forschungsgemeinschaft.

2. Erindale College, University of Toronto, Mississauga, Ontario, CANADA L5L 1 C6.

3. Fachbereich Biologie, Institut fur Zoologie, Technische Hochschule, 61 Darmstadt, Schnittspahnstr. 3, Federal Republic of Germany.

4. The Lindenwood Colleges, Saint Charles Missouri, U.S.A. 63301.

Manuscript received by the editor August 5, 1982. 
pendently. The parasite queen finds a colony of her host species, enters it, and somehow usurps the role of a host-species queen. The host-species workers then raise the parasite queen's brood.

Species of temporary parasites possess a completely functional worker caste. At first, the temporary-parasite workers and the hostspecies workers exist alongside one another. However, when the host-species workers die, they are not replaced; and a pure colony of the temporary-parasite species develops. The workers of slavemaking parasites are highly specialized for fighting and raiding the nests of host-species colonies; and as a consequence of their raids during which they capture host-species worker pupae and larvae, a force of host-species workers (or "slaves") is maintained. Inquiline parasites either have no worker caste at all; or, if one is present, the workers seem to play no role in maintaining the colony. In some cases, a continuing supply of host-species workers is maintained by the host-species queen's coexisting with the inquiline queen (Buschinger, 1970; Wilson, 1971).

This paper presents data concerning several aspects of the behavioral biology of three North American species of the ant genus Leptothorax Mayr: L. ambiguus Emery, L. curvispinosus Mayr, and $L$. longispinosus Roger. These species interested us because they are hosts to three closely related parasite species. All three species are enslaved by the obligatory slave-makers $L$. duloticus Wesson and Harpagoxenus americanus (Emery); and L. curvispinosus is the host of the workerless inquiline species L. minutissimus $\mathbf{M}$. R. Smith (Alloway, 1979; Creighton, 1950). Thus, studies of the behavior and ecology of these three nonparasitic species may elucidate the ethological and ecological circumstances under which social parasitism evolves and is maintained.

\section{Number of Queens AND the Sex of Broods in Nests}

Headley (1943) and Talbot (1957) reported that the number of queens in nests of $L$. curvispinosus and L. longispinosus is quite variable. Some nests contain several dealate queens, some contain one, and some contain none at all. Observations indicated that the number of queens in nests of L. ambiguus is also variable (Alloway, unpublished data). In addition, we found that many queenless nests of all three species contained broods which either included worker and queen pupae at the time of collection or matured into worker and queen (as well as male) pupae. 
These observations raised a number of hypotheses. Nests containing more than one dealate queen suggested that some colonies of $L$. ambiguus, L. curvispinosus, and L. longispinosus are polygynous. The production of female pupae in queenless nests raised at least three possibilities which are not mutually exclusive. First, a queenless nest might be part of a polydomous colony with the female pupae being the progeny of one or more queens located in another nest at the time of collection. Second, these species might possess numerous ergatomorphic reproductives, individuals which resemble workers morphologically but which have a spermatheca, can be inseminated, and are capable of laying fertilized female eggs (Buschinger 1975, 1978). Third, a queenless nest might be the remnant of a colony whose queen had died.

\section{Materials and Methods}

Over a two-year period, nests of L. ambiguus, L. curvispinosus, and L. longispinosus were collected during late March, April, May and early June; and weekly collection of L. ambiguus and L. longispinosus were obtained throughout June, July, and August of one summer. We recorded the number of queens present in every nest. In nests containing pupae at the time of collection, the kind of pupae present (queen, worker, and/or male) was also noted. Finally, nests of all three species were collected during the early spring of one year and cultured in the laboratory to determine the sex and caste of the pupae which matured from larvae present in the nests at the time of collection.

\section{Results}

Table 1 contains data regarding the proportions of nests collected during the springs of two years which contained 0,1 , or more than 1 queen. About $1 / 5$ of the nests contained more than one dealate queen; about $1 / 3$ contained no queen; and the remainder contained 1 queen. Tables 2,3 , and 4 reveal that the proportion of queenless nests was similar across years and throughout the season.

Table 2 presents the numbers and proportions of nests of all three species collected in the spring and containing pupae of various kinds. Table 3 presents similar data for nests of $L$. ambiguus and $L$. longispinosus collected throughout the summer. These tables reveal that many freshly collected queenless nests contained female (worker and queen) pupae. Table 4 presents data concerning the broods 
Table 1. Number and Percent of Nests of L. ambiguus, L. curvispinosus, and L. longispinosus Containing 0,1 , or More Than 1 Queen

\begin{tabular}{lcccc}
\hline $\begin{array}{l}\text { Number of } \\
\text { Queens }\end{array}$ & $\begin{array}{c}\text { L. } \\
\text { ambiguus }\end{array}$ & $\begin{array}{c}\text { L. } \\
\text { curvispinosus }\end{array}$ & $\begin{array}{c}\text { L. } \\
\text { longispinosus }\end{array}$ & Total \\
\hline 0 & $453(29.7 \%)$ & $177(36.3 \%)$ & $237(37.0 \%)$ & $867(32.7 \%)$ \\
1 & $765(50.3 \%)$ & $228(46.7 \%)$ & $311(48.6 \%)$ & $1304(49.2 \%)$ \\
More than 1 & $304(20.1 \%)$ & $83(17.0 \%)$ & $92(14.4 \%)$ & $479(18.1 \%)$ \\
$\quad$ Total & $1522(100.0 \%)$ & $488(100.0 \%)$ & $640(100.0 \%)$ & $2650(100.0 \%)$ \\
\hline
\end{tabular}

which matured from queenless and queenright nests of the three species collected in the early spring and then cultured in the laboratory. Once again, many queenless nests produced female pupae.

\section{Discussion}

First, we want to stress that variability in the number of queens in nests of $L$. curvispinosus and L. longispinosus, first noted by Headley (1943) and Talbot (1957), is not a local or transitory phenomenon and note that the number of queens in nests of $L$. ambiguus is also quite variable. However, of far greater importance is the large proportion of queenless nests of all three species which produce female (as well as male) pupae. This fact raised questions about the possible existence of ergatomorphic reproductives and polydomy.

\section{Polygyny and Worker Fertility}

To demonstrate that a species of ant is facultatively polygynous, one must show that two or more fertile inseminated females can coexist in nests. Headley (1943) and Talbot (1957) reported the occurrence of multiple queens in some nests of $L$. curvispinosus and L. longispinosus. However, these authors did not determine whether more than one queen was inseminated and egg-laying. Wilson (1974a, b) observed several multiple-queen nests of L. curvispinosus and reported that all the queens laid eggs. However, as we shall show, uninseminated queens and workers sometimes lay eggs. Thus, the question of the occurrence of polygyny involving fertile inseminated queens remained open. In addition, the production of female pupae in many queenless nests of $L$. ambiguus, $L$. curvispinosus, and L. longispinosus suggested, as one possibility, the hypothesis that these species might possess frequent ergatomorphic female reproductives. 
Table 2. Number and Percent of Queenright and Queenless Nests of $L$. ambiguus, L. curvispinosus, and L. longispinousus Containing Pupae and/or Alate Reproductives of Various Types at the Time of Collection (1977-78)

\begin{tabular}{|c|c|c|c|c|}
\hline \multicolumn{5}{|c|}{ Queenright Nests } \\
\hline Species & $\begin{array}{c}\uparrow \text { and } / \text { or } \\
\Varangle \zeta \text { Only }\end{array}$ & $\begin{array}{c}q \text { and } / \text { or } \\
\Varangle \text { and } \delta\end{array}$ & ¿̂ Only & Total \\
\hline L. ambiguus & $180(83.3 \%)$ & $31(14.4 \%)$ & $5(2.3 \%)$ & $216(100.0 \%)$ \\
\hline L. curvispinosus & $23(53.5 \%)$ & $19(44.2 \%)$ & $1(2.3 \%)$ & $43(100.0 \%)$ \\
\hline L. longispinosus & $76(66.1 \%)$ & $33(28.7 \%)$ & $6(5.2 \%)$ & $115(100.0 \%)$ \\
\hline Total & $279(74.6 \%)$ & $83(22.2 \%)$ & $12(3.2 \%)$ & $374(100.0 \%)$ \\
\hline \multicolumn{5}{|c|}{ Queenless Nests } \\
\hline Species & $\begin{array}{c}\uparrow \text { and / or } \\
\Varangle \subsetneq \text { Only }\end{array}$ & $\begin{array}{c}q \text { and / or } \\
\not \emptyset \text { and } \hat{\phi}\end{array}$ & ô Only & Total \\
\hline L. ambiguus & $90(80.4 \%)$ & $16(14.3 \%)$ & $6(5.4 \%)$ & $112(100.0 \%)$ \\
\hline L. curvispinosus & $19(59.4 \%)$ & $9(28.1 \%)$ & $4(12.5 \%)$ & $32(100.0 \%)$ \\
\hline L. longispinosus & $35(50.0 \%)$ & $24(34.3 \%)$ & $11(15.7 \%)$ & $70(100.0 \%)$ \\
\hline Total & $144(67.3 \%)$ & $49(22.9 \%)$ & $21(9.8 \%)$ & $214(100.0 \%)$ \\
\hline
\end{tabular}

Materials and Methods

To determine whether polygyny involving inseminated queens occurs in these species, we dissected all the queens present in samples of nests containing more than one dealate queen. To determine whether ergatomorphic female reproductives occur frequently, we dissected all the "workers" from five queenless nests of each species which had produced female broods when cultured in the laboratory.

For each queen or worker dissected, we noted the following characteristics:

a. the number of ovarioles.

b. the length of the ovaries. In young virgin queens, the ovaries are thin and about $3 / 4$ the length of the queen's gaster. When a queen becomes fertile, her ovaries grow until they eventually become as long as her entire body. In old fertile queens, the folded and coiled ovarioles enlarge until they almost completely fill the gaster.

c. the presence or absence of any growing oocytes in the ovarioles. The ovarioles of sterile individuals contain no oocytes; and in hibernating fertile queens, the oocytes are transparent. As yolk is 
deposited in growing oocytes, they become opaque; and ripe eggs are white.

d. the presence or absence of corpora lutea in the bases of the ovarioles. These yellowish residues of nutritional cells remain in the ovaries when eggs have been laid.

e. the presence or absence of a full or empty spermatheca. Individuals with no spermatheca or an empty spermatheca are incapable of laying fertilized eggs which develop into workers or queens. An empty spermatheca appears as a small, transparent bladder on the common oviduct. When full of sperm, the spermatheca is white and superficially resembles a ripe egg in size and coloration.

Results:

Our dissections enabled us to distinguish several physiologically different kinds of queens. To simplify the presentation of data, we

Table 3. Number of Queenright and Queenless Nests of L. ambiguus and L. longispinosus Collected during June, July, and August and the Composition of their Broods

\section{L. ambiguus}

\begin{tabular}{|c|c|c|c|c|c|c|}
\hline & \multicolumn{3}{|c|}{ Queenless nests } & \multicolumn{3}{|c|}{ Queenright nests } \\
\hline & \multicolumn{3}{|c|}{ Type of Brood } & \multicolumn{3}{|c|}{ Type of Brood } \\
\hline & $\delta$ only & $q$ and $\varnothing$ & $\begin{array}{l}q, \phi, \\
\text { and } \delta\end{array}$ & $\delta$ only & $q$ and $\not$ & $\begin{array}{l}\text { Q, } \varnothing, \\
\text { and } \delta\end{array}$ \\
\hline June & 0 & 5 & 0 & 0 & 28 & 0 \\
\hline July & 0 & 11 & 17 & 1 & 37 & 71 \\
\hline August & 2 & 9 & 8 & 2 & 32 & 77 \\
\hline
\end{tabular}

L. longispinosus

Queenless nests

Queenright nests

\begin{tabular}{|c|c|c|c|c|c|c|}
\hline & \multicolumn{3}{|c|}{ Queenless nests } & \multicolumn{3}{|c|}{ Queenright nests } \\
\hline & \multicolumn{3}{|c|}{ Type of Brood } & \multicolumn{3}{|c|}{ Type of Brood } \\
\hline & $\lesssim$ only & $\phi$ and $\not \varnothing$ & $\begin{array}{l}q, \varnothing, \\
\text { and } \phi\end{array}$ & ô only & $q$ and $\not$ & $\begin{array}{l}\text { ㅇ, } \phi \bar{t}, \\
\text { and } \delta\end{array}$ \\
\hline June & 0 & 0 & 1 & 0 & 2 & 1 \\
\hline July & 0 & 0 & 4 & 0 & 1 & 12 \\
\hline August & 0 & 0 & 1 & 0 & 0 & 3 \\
\hline
\end{tabular}


will employ a set of terms developed by Buschinger (1968) to describe these individuals. These terms are defined as follows:

A-queen: An inseminated, fully fertile queen. The ovaries are as long, or nearly as long, as the whole body. The ovarioles contain many developing oocytes; and conspicuous corpora lutea are present. The spermatheca is full of sperm. Such queens are normally more than a year old.

b-queen: An inseminated young queen. At the time of our study (in mid-summer), the ovaries were about half their eventual length and contained developing oocytes. Sometimes a small corpus luteum was visible in the base of one or two ovarioles. The spermatheca was full. We believe that these females had mated the previous summer and were in the process of becoming fully fertile. After mating, newly inseminated queens have very short ovarioles with no developing oocytes. If a nest, before the mating season, contains one or more A-queens and one or more b-queens with growing oocytes, we conclude that that nest represents all or part of a colony which adopted one or more newly mated queens the previous summer.

Table 4. Number and Percent of Queenright and Queenless Nests of L. ambiguus, L. curvispinosus and L. longispinosus Collected in the Spring of 1979 which Produced Broods of Various Compositions when Cultured in the Laboratory

\begin{tabular}{|c|c|c|c|c|}
\hline \multicolumn{5}{|c|}{ Queenright Nests } \\
\hline Species & $\begin{array}{c}\text { ㅇ and / or } \\
\not \varnothing \text { only }\end{array}$ & $\begin{array}{l}q \text { and } / \text { or } \\
\not \varnothing \text { and } \delta\end{array}$ & $\delta$ only & Total \\
\hline L. ambiguus & $68(47.5 \%)$ & $60(42.0 \%)$ & $15(10.5 \%)$ & $143(100.0 \%)$ \\
\hline L. curvispinosus & $95(65.5 \%)$ & $49(33.8 \%)$ & $1(0.7 \%)$ & $145(100.0 \%)$ \\
\hline L. longispinosus & $42(56.0 \%)$ & $22(29.3 \%)$ & $11(14.7 \%)$ & $75(100.0 \%)$ \\
\hline Total & $205(56.5 \%)$ & $131(36.1 \%)$ & $27(7.4 \%)$ & $363(100.0 \%)$ \\
\hline \multicolumn{5}{|c|}{ Queenless Nests } \\
\hline Species & $\begin{array}{c}q \text { and / or } \\
\not \succ \text { only }\end{array}$ & $\begin{array}{l}q \text { and } / \text { or } \\
\not \zeta \text { and } \hat{\sigma}\end{array}$ & $\hat{\sigma}$ only & Total \\
\hline L. ambiguus & $37(52.1 \%)$ & $24(33.8 \%)$ & $10(14.1 \%)$ & $71(100.0 \%)$ \\
\hline L. curvispinosus & $35(43.2 \%)$ & $38(46.9 \%)$ & $8(9.9 \%)$ & $81(100.0 \%)$ \\
\hline L. longispinosus & $12(38.7 \%)$ & $12(38.7 \%)$ & $7(22.6 \%)$ & $31(100.0 \%)$ \\
\hline Total & $84(45.9 \%)$ & $74(40.4 \%)$ & $25(13.7 \%)$ & $183(100.0 \%)$ \\
\hline
\end{tabular}


c-queen: An uninseminated, old, sterile female. The ovaries are short and contain no oocytes. The spermatheca, if present, is empty; but it may not be present. The wing muscles are degenerate and have been replaced by fat body. (The term d-queen would denote a young dealate female which had not been inseminated. The reproductive organs resemble those of cqueens, but the wing muscles have not yet degenerated. We found no d-queens, probably because we performed our dissections before the sexual brood had eclosed.)

C-queen: An uninseminated, egg-laying female with ovarioles like those of an A-queen. Sometimes there is no spermatheca. In this paper, we report the occurrence of significant numbers of individuals of this type for the first time in Leptothoracine ants. However, they occur rather frequently in colonies of Formica polyctena Foerster (Ehrhardt 1970) and Monomorium pharaonis (L.) (Petersen \& Buschinger 1971). The origin of these females in nests of L. ambiguus, L. curvispinosus, and L. longispinosus is unclear. They may be old individuals which were once inseminated but whose supply of sperm has been exhausted. However, the existence of egg-layers with no spermatheca indicates that insemination is not a necessary prerequisite for fertility. Recently U. Winter (personal communication) found that Harpagoxenus sublaevis males often transmit very little or no sperm during their first copulation. Thus, a queen which had mated only once with such a male might become fertile after receiving only the secretions of the males's accessory glands. Perhaps a similar mechanism accounts for the existence of C-queens in these species of Leptothorax.

The results of the dissections of queens of each species and of workers will be presented separately.

\section{Leptothorax ambiguus}

A total of 88 dealate females from 30 multiple-queen colonies was dissected. Only about $1 / 2$ the multiple-queen nests contained more than one A-queen and were thus "truly polygynous" (see Table 5). Three of these truly polygynous nests also contained one or two b-queens and were thus in the process of developing polygyny to a higher degree. 
Table 5. Number and Type of Dealate Females in Multiple-Queen Colonies of Leptothorax ambiguus

\begin{tabular}{|c|c|c|c|c|c|c|}
\hline $\begin{array}{c}\text { Colony } \\
\text { No. }\end{array}$ & $\begin{array}{c}\text { n Dealate } \\
\text { 우 }\end{array}$ & A-우우 & b- +9 & $\mathrm{c}-Q \%$ & $\mathrm{C}-$ - 9 우 & Remarks \\
\hline 1 & 2 & 2 & - & - & - & \\
\hline 2 & 2 & 2 & - & - & - & \\
\hline 3 & 2 & 2 & - & - & - & \\
\hline 4 & 2 & 2 & - & - & - & \\
\hline 5 & 2 & 2 & - & - & - & \\
\hline 6 & 2 & 2 & - & - & - & Colonies No. \\
\hline 7 & 2 & 2 & - & - & - & $1-15$ are truly \\
\hline 8 & 2 & 2 & - & - & - & polygynous \\
\hline 9 & 4 & 2 & 2 & - & - & \\
\hline 10 & 3 & 2 & - & - & 1 & \\
\hline 11 & 3 & 3 & - & - & - & \\
\hline 12 & 3 & 2 & 1 & - & - & \\
\hline 13 & 3 & 2 & 1 & - & - & \\
\hline 14 & 5 & 4 & - & - & 1 & \\
\hline 15 & 13 & 2 & - & 3 & 8 & \\
\hline 16 & 2 & 1 & 1 & - & - & \\
\hline 17 & 2 & 1 & 1 & - & - & \\
\hline 18 & 2 & 1 & 1 & - & - & Colonies No. \\
\hline 19 & 2 & 1 & 1 & - & - & $16-23$ are \\
\hline 20 & 3 & 1 & 2 & - & - & becoming \\
\hline 21 & 3 & $i$ & 1 & - & 1 & polygynous \\
\hline 22 & 3 & 1 & 1 & - & 1 & \\
\hline 23 & 2 & - & 2 & - & - & \\
\hline 24 & 2 & 1 & - & - & $1+$ & Colony fragment? \\
\hline 25 & 2 & - & 1 & - & $1+$ & $+C-\rho$ without \\
\hline 26 & 2 & 1 & - & - & 1 & spermatheca \\
\hline 27 & 2 & 1 & - & - & 1 & \\
\hline 28 & 3 & - & 1 & - & 2 & \\
\hline 29 & 2 & - & - & 2 & - & Colony fragment? \\
\hline 30 & 6 & - & - & 2 & 4 & \\
\hline Total & 88 & 43 & 16 & 7 & 22 & \\
\hline
\end{tabular}

Another 7 nests (No. 16-23 in Table 5) were in the process of becoming polygynous. They contained $1 \mathrm{~A}$-queen and 1 or 2 bqueens. One nest (No. 23) contained 2 b-queens only and was thus also becoming polygynous, although it lacked an A-queen. A number of nests contained one or more C-queens. Most of these 
individuals were living with A-queens. Two C-queens without a spermatheca were found in this sample (in nests No. 24 and 25).

\section{Leptothorax curvispinosus}

A total of 64 dealate queens from a sample of 23 multiple-queen nests was dissected. As was the case for L. ambiguus, we found all four categories of dealate females in L. curvispinosus (see Table 6). However, approximately $3 / 4$ of the curvispinosus nests (74\%) contained multiple A-queens, as compared to only about $1 / 2$ of the ambiguus nests. In addition, all 7 of the multiple-queen curvispinosus nests which had only $1 \mathrm{~A}$-queen contained one or more b-queens and were thus becoming polygynous. The total number of $\mathrm{C}$-queens was much lower in curvispinosus than in ambiguus. However, we found $3 \mathrm{C}$-queens with no spermatheca; and 2 of these were fully fertile.

\section{Leptothorax longispinosus}

A total of 79 queens from a sample of 26 multiple-queen nests was dissected. The proportion of nests containing more than one A-queen was $65 \%$; and all but one of the other nests contained either one or more b-queens living with an A-queen or more than one b-queen without an A-queen (see Table 7). The only exception was nest No. 23 which contained $7 \mathrm{C}$-queens living with a single Aqueen. One of these $\mathrm{C}$-queens had no spermatheca.

4. The number of ovarioles in queens

Table 8 shows that queens of L. ambiguus usually have 6 ovarioles (both ovaries combined). Six is the usual number of ovarioles for most European species of the subgenus Leptothorax sensu stricto (= Myrafant M. R. Smith 1950) and for species of the subgenus Mychothorax (=Leptothorax sensu M. R. Smith) (Buschinger, unpublished data). However, L. curvispinosus queens most commonly have 8 ovarioles; and $L$. longispinosus queens most commonly have 7. Moreover, the number of ovarioles in L. longispinosus queens is very variable; and the distribution of ovarioles in single specimens of this species can be quite asymmetrical. One queen with 10 ovarioles had 6 on the left side and 4 on the right; another with 11 ovarioles had 4 on the left and 7 on the right. There was no evidence that the number of ovarioles is correlated with a queen's function in a nest. The number of ovarioles often varied considerable among 
Table 6. Numbers and Type of Dealate Females in Multiple-Queen Colonies of Leptothorax curvispinosus

\begin{tabular}{|c|c|c|c|c|c|c|}
\hline $\begin{array}{l}\text { Colony } \\
\text { No. }\end{array}$ & $\begin{array}{c}\text { n Dealate } \\
\text { 우 }\end{array}$ & A-우운 & b-pot & c- $-q$ ? & C- 9 우 & Remarks \\
\hline 1 & 2 & 2 & - & - & - & \\
\hline 2 & 2 & 2 & - & - & - & \\
\hline 3 & 2 & 2 & - & - & - & \\
\hline 4 & 2 & 2 & - & - & - & \\
\hline 5 & 2 & 2 & - & - & - & \\
\hline 6 & 2 & 2 & - & - & - & Colony No. \\
\hline 7 & 2 & 2 & - & - & - & $1-16$ truly \\
\hline 8 & 2 & 2 & - & - & - & polygynous \\
\hline 9 & 2 & 2 & - & - & - & \\
\hline 10 & 3 & 3 & - & - & - & \\
\hline 11 & 3 & 3 & - & - & - & \\
\hline 12 & 3 & 3 & - & - & - & \\
\hline 13 & 4 & 4 & - & - & - & \\
\hline 14 & 4 & 2 & 2 & - & - & \\
\hline 15 & 4 & 3 & 1 & - & - & \\
\hline 16 & 4 & 3 & - & & $1^{+}$ & ${ }^{+} \mathrm{C}$-Qqwithout \\
\hline 17 & 2 & 1 & 1 & - & - & spermatheca \\
\hline 18 & 2 & 1 & 1 & - & - & Colony No. \\
\hline 19 & 4 & 1 & 3 & - & - & $17-23$ \\
\hline 20 & 3 & 1 & 1 & $1^{+}$ & - & becoming polygynous \\
\hline 21 & 3 & 1 & 1 & - & 1 & ${ }^{+} \mathrm{c}-\mathrm{Q}$ without \\
\hline 22 & 3 & 1 & 1 & - & 1 & spermatheca \\
\hline 23 & 4 & 1 & 3 & - & - & $\begin{array}{l}{ }^{+} \mathrm{C}-9 \text { without } \\
\text { spermatheca }\end{array}$ \\
\hline Total & 64 & 46 & 14 & 1 & 3 & \\
\hline
\end{tabular}

queens in single nests, especially in L. longispinosus. Moreover, band $\mathrm{C}$-queens on average had no fewer ovarioles than A-queens.

\section{Workers}

All the queenless nests whose workers were dissected contained one or more egg-laying individuals (see Table 9). However, none of the fertile workers possessed a spermatheca. Thus, we presume that all their offspring are males. Workers invariably had only two ovarioles (one per ovary); and these were never as long and never contained as many corpora lutea as the ovarioles of egg-laying A- and $\mathrm{C}$-queens. Thus, the number of eggs produced by a fertile worker is probably much less than that produced by a queen. 
Table 7. Numbers and Type of Dealate Females in Multiple-Queen Colonies of Leptothorax longispinosus

\begin{tabular}{|c|c|c|c|c|c|}
\hline $\begin{array}{l}\text { Colony } \\
\text { No. }\end{array}$ & $\begin{array}{c}\mathrm{n} \text { dealate } \\
\text { 우우 }\end{array}$ & A-우우 & b- +9 우 & $\mathrm{C}-q 9+9$ & Remarks \\
\hline 1 & 2 & 2 & - & - & \\
\hline 2 & 2 & 2 & - & - & \\
\hline 3 & 2 & 2 & - & - & \\
\hline 4 & 2 & 2 & - & - & \\
\hline 5 & 2 & 2 & - & - & \\
\hline 6 & 2 & 2 & - & - & \\
\hline 7 & 2 & 2 & - & - & \\
\hline 8 & 2 & 2 & - & - & Colonies No. $1-17$ truly \\
\hline 9 & 2 & 2 & - & - & polygynous \\
\hline 10 & 2 & 2 & - & - & \\
\hline 11 & 3 & 3 & - & - & \\
\hline 12 & 3 & 3 & - & - & \\
\hline 13 & 4 & 4 & - & - & \\
\hline 14 & 4 & 4 & - & - & \\
\hline 15 & 6 & 6 & - & - & \\
\hline 16 & 3 & 2 & 1 & - & \\
\hline 17 & 3 & 2 & 1 & - & \\
\hline 18 & 2 & 1 & 1 & - & \\
\hline 19 & 2 & 1 & 1 & - & Colonies No. 18-22 and \\
\hline 20 & 3 & 1 & 2 & - & No. $24-26$ becoming \\
\hline 21 & 3 & 1 & 2 & - & polygynous \\
\hline 22 & 4 & 1 & 3 & - & \\
\hline 23 & 8 & 1 & - & $7^{+}$ & ${ }^{+} 1 \mathrm{C}-\mathrm{Q}$ without spermatheca \\
\hline 24 & 2 & - & 2 & - & \\
\hline 25 & 4 & - & 4 & - & \\
\hline 26 & 5 & - & 5 & - & \\
\hline Total & 79 & 50 & 22 & 7 & \\
\hline
\end{tabular}

Table 8. Ovariole Numbers in Queens of Leptothorax ambiguus, L. curvispinosus, and L. longispinosus

\begin{tabular}{|c|c|c|c|c|c|c|c|c|c|c|}
\hline n. ovarioles & 4 & 5 & 6 & 7 & 8 & 9 & 10 & 11 & nopo & \\
\hline L. ambiguus & 1 & 1 & 82 & 4 & - & - & - & - & 88 & $\begin{aligned} \overline{\mathrm{x}} & =5.99 \\
\mathrm{~s} & =0.39\end{aligned}$ \\
\hline L. curvispinosus & - & - & - & 11 & 44 & 6 & - & - & 61 & $\begin{aligned} \bar{x} & =7.92 \\
\mathrm{~s} & =0.53\end{aligned}$ \\
\hline L. longispinosus & 1 & 4 & 19 & 32 & 18 & 1 & 2 & 2 & 79 & $\begin{aligned} \bar{x} & =7.05 \\
\mathrm{~s} & =1.22\end{aligned}$ \\
\hline
\end{tabular}


Discussion:

These data establish two important points. First, polygyny involving multiple inseminated queens occurs in some nests of $L$. ambiguus, L. curvispinosus, and L. longispinosus; and polygynous nests imply the existence of polygynous colonies. Polygyny in these three members of the subgenus Leptothorax sensu stricto as well as in L. schaumi and L. flavicornis (Buschinger, unpublished observations) is somewhat surprising in that the majority of European members of the subgenus are strictly monogynous (Buschinger 1967). The form of polygyny exhibited by L. ambiguus, L. curvispinosus, and L. longispinosus is also interesting in that the frequent joint presence of $\mathrm{A}$ - and $\mathrm{b}$-queens indicates that colonies of these species can adopt young conspecific queens. We will argue below that this tendency to adopt queens is important for understanding the evolutionary origins of parasitic colony foundation.

Second, although our dissections of workers in queenless colonies which produced female pupae revealed that some workers lay eggs, our failure to find any workers with a spermatheca indicates that ergatomorphic reproductive females of the kind seen in the slavemaker Harpagoxenus sublaevis are at least not common in L. ambiguus, L. curvispinosus, and L. longispinosus.

\section{Polydomy}

This latter finding suggested two possibilities which are not mutually exclusive:

a. Some queenless nests of these species which produce broods containing female pupae may be parts of polydomous colonies. In such cases, the female pupae would be the progeny of queens located in other nests at the time of collection.

b. Some queenless nests may represent declining colonies with no queen. The female pupae are the offspring of a dead queen.

Materials and Methods

We collected groups of acorn nests which were very close together in nature and brought the nests back to the laboratory where the ants were established in artificial nests. We then arranged the artificial nests in arenas to duplicate the spatial arrangement of the natural nests and observed the ensuing behavioral interactions. As controls, we tested the effect of placing nests from different parts of 
Table 9. Numbers and Percent of Sterile and Fertile Workers in Queenless Nests of L. ambiguus, L. curvispinosus, and L. longispinosus

\begin{tabular}{|c|c|c|c|}
\hline \multicolumn{4}{|c|}{ L. ambiguus } \\
\hline Nest No. & Sterile Workers & Fertile Workers & Total \\
\hline 1 & $7(64 \%)$ & $4(36 \%)$ & 11 \\
\hline 2 & $9(60 \%)$ & $6(40 \%)$ & 15 \\
\hline 3 & $12(71 \%)$ & $5(29 \%)$ & 17 \\
\hline 4 & $12(86 \%)$ & $2(14 \%)$ & 14 \\
\hline 5 & $24(80 \%)$ & $6(20 \%)$ & 30 \\
\hline \multicolumn{4}{|c|}{ L. curvispinosus } \\
\hline Nest No. & Sterile Workers & Fertile Workers & Total \\
\hline 1 & $13(93 \%)$ & $1(7 \%)$ & 14 \\
\hline 2 & $18(72 \%)$ & $7(18 \%)$ & 25 \\
\hline 3 & $17(81 \%)$ & $4(19 \%)$ & 21 \\
\hline 4 & $16(70 \%)$ & $7(30 \%)$ & 23 \\
\hline 5 & $15(71 \%)$ & $6(29 \%)$ & 21 \\
\hline \multicolumn{4}{|c|}{ L. longispinosus } \\
\hline Nest No. & Sterile Workers & Fertile Workers & Total \\
\hline 1 & $12(67 \%)$ & $6(33 \%)$ & 18 \\
\hline 2 & $5(56 \%)$ & $4(44 \%)$ & 9 \\
\hline 3 & $5(21 \%)$ & $19(79 \%)$ & 24 \\
\hline 4 & $17(74 \%)$ & $6(26 \%)$ & 23 \\
\hline 5 & $7(50 \%)$ & $7(50 \%)$ & 14 \\
\hline
\end{tabular}

the same collection site much closer together than they had been found and of placing nests from different sites together.

Two kinds of arenas were employed. One type consisted of a $1 \mathrm{~m}^{2}$ area on a table top. The other was a square plexiglass enclosure having an area of $2025 \mathrm{~cm}^{2}$ surrounded by plexiglass walls $6 \mathrm{~cm}$ high. The ants were confined to the arenas by a thick barrier of petroleum jelly. Colonies were fed an artificial ant diet (Bhatkar \& Whitcomb 1970) three times a week; water was continuously available. The experimental room was kept on a 15-h light and 9-h dark photoperiod at a temperature of $22^{\circ} \mathrm{C} \pm 1{ }^{\circ} \mathrm{C}$.

Results

A total of 28 experiments involving 96 nests of L. ambiguus and 5 experiments involving 11 nests of $L$. longispinosus were performed. 
Certain pertinent facts about each experiment are contained in Table 10.

The most frequent result for nests which had been close together in nature was so-called "fusion". After a day or two, the ants from the different nests peacefully moved into one of the artificial nests and remained there indefinitely. We are not sure why fusion occurred so frequently in the laboratory. One factor may have been that our artificial nests are somewhat larger than the average acorn. In any case, these peaceful mergers suggest that the ants from adjacent nests were members of the same colony and are thus compatible with the polydomy hypothesis.

Other experiments (e.g. L. ambiguus experiments 9, 10, and 23 and $L$. longispinosus experiment 5 ) supported the polydomy hypothesis more dramatically. The ants continued to occupy more than one nest among which they maintained a more or less continual exchange of workers, brood, and queens. Thus, over a period of several days, a nest was sometimes polygynous, sometimes monogynous, and sometimes queenless. In other experiments, (e.g. $L$. ambiguus experiments $12,13,14,15,16,22,24)$, it appeared that we observed interactions between two polydomous colonies or between a polydomous and a monodomous colony. For example, in experiments 15 and 16, we had examples of four nests which had been found in two close pairs separated by a somewhat greater distance. The ants from each pair of nests quickly fused, but there was prolonged fighting among the ants from the different pairs of nests.

The results of the control experiments also supported the polydomy hypothesis. Ants from nests not found close together in nature did not usually coexist peacefully. When nests from different parts of the same collection site or from different sites were placed near one another, the result was usually widespread and protracted fighting. However, we observed two exceptions to this rule. In $L$. ambiguus experiment 19, 3 nests which had been an average of $96 \mathrm{~cm}$ apart in nature were placed together in a $2025-\mathrm{cm}^{2}$ arena. There was no fighting; and after 12 days, the ants from two queenright nests which had been $118 \mathrm{~cm}$ apart in nature peacefully moved into one nest. Even more surprising was the fusion of ants in two queenright nests from different collection sites which we observed in L. ambiguus experiment 18 . We cannot explain these anomalous results, although we speculate that these species have a limited 


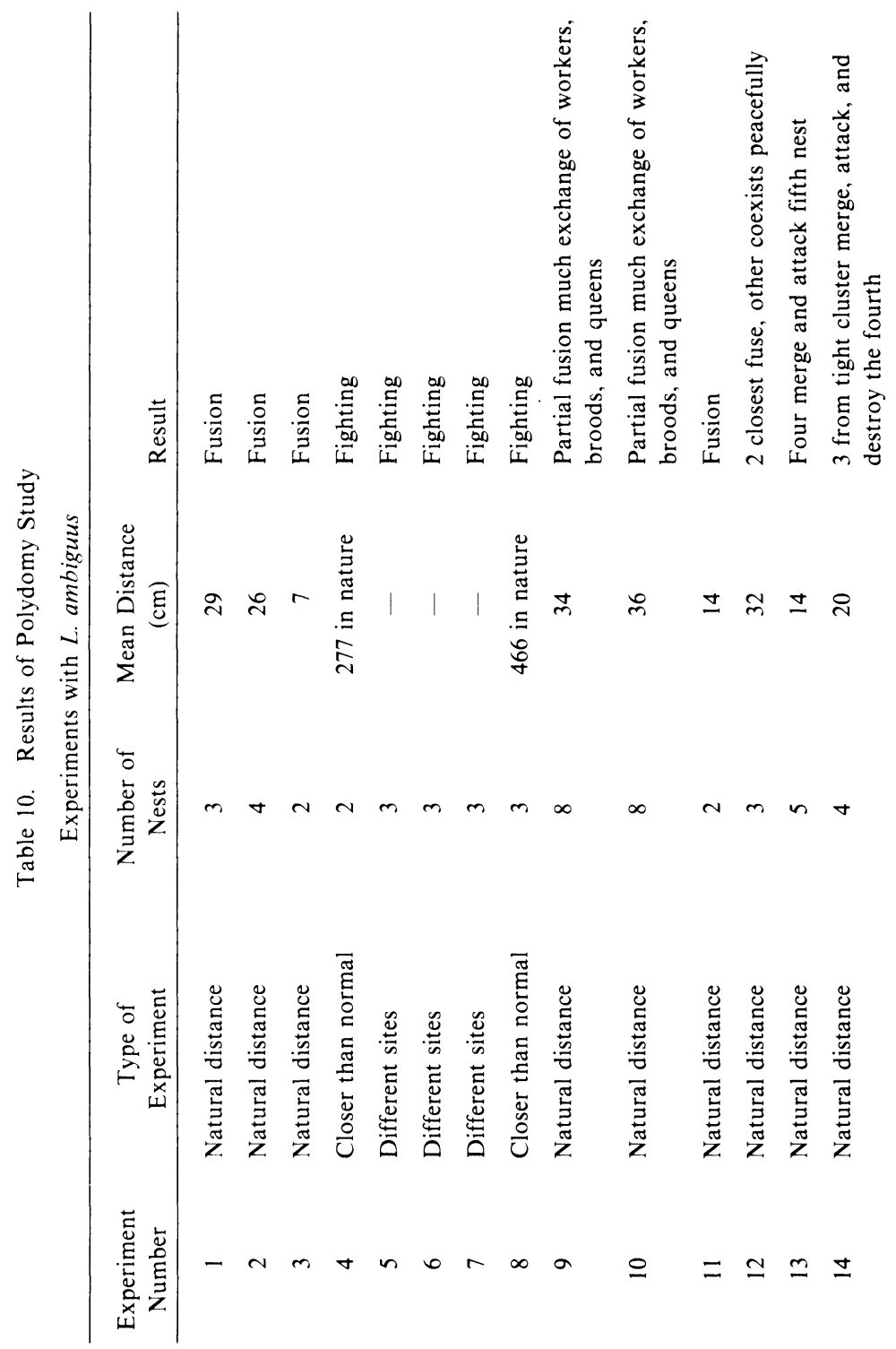




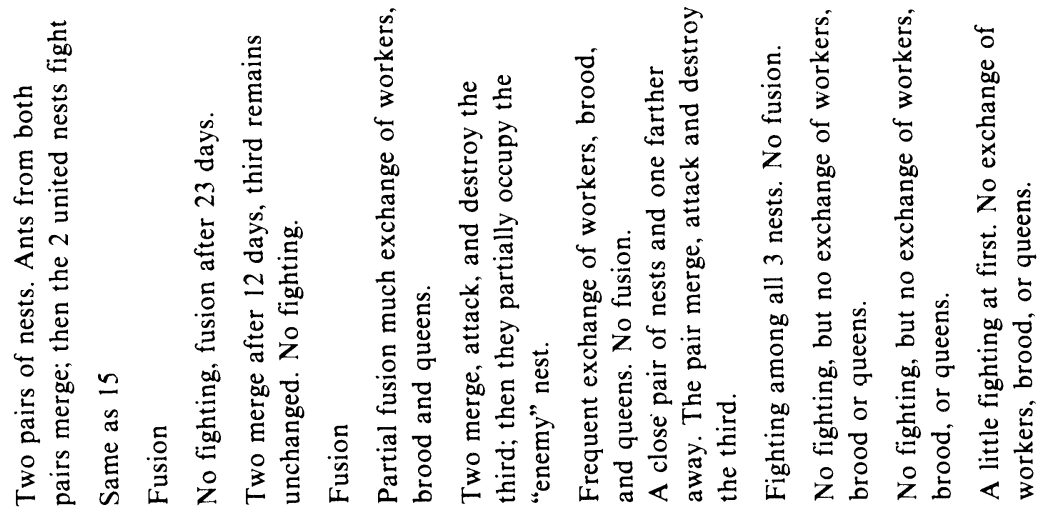

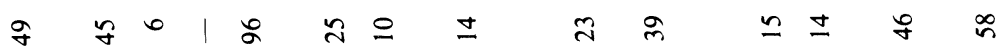

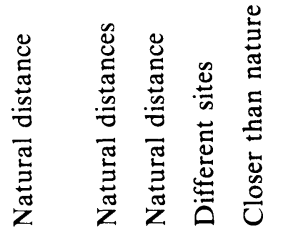

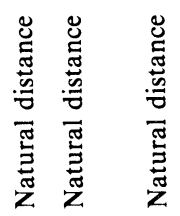

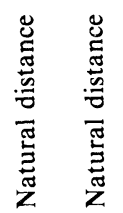

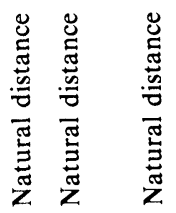

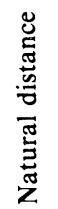

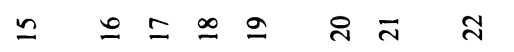
$\tilde{\sim}$
$\approx$ กั
$\stackrel{\infty}{\sim}$ 


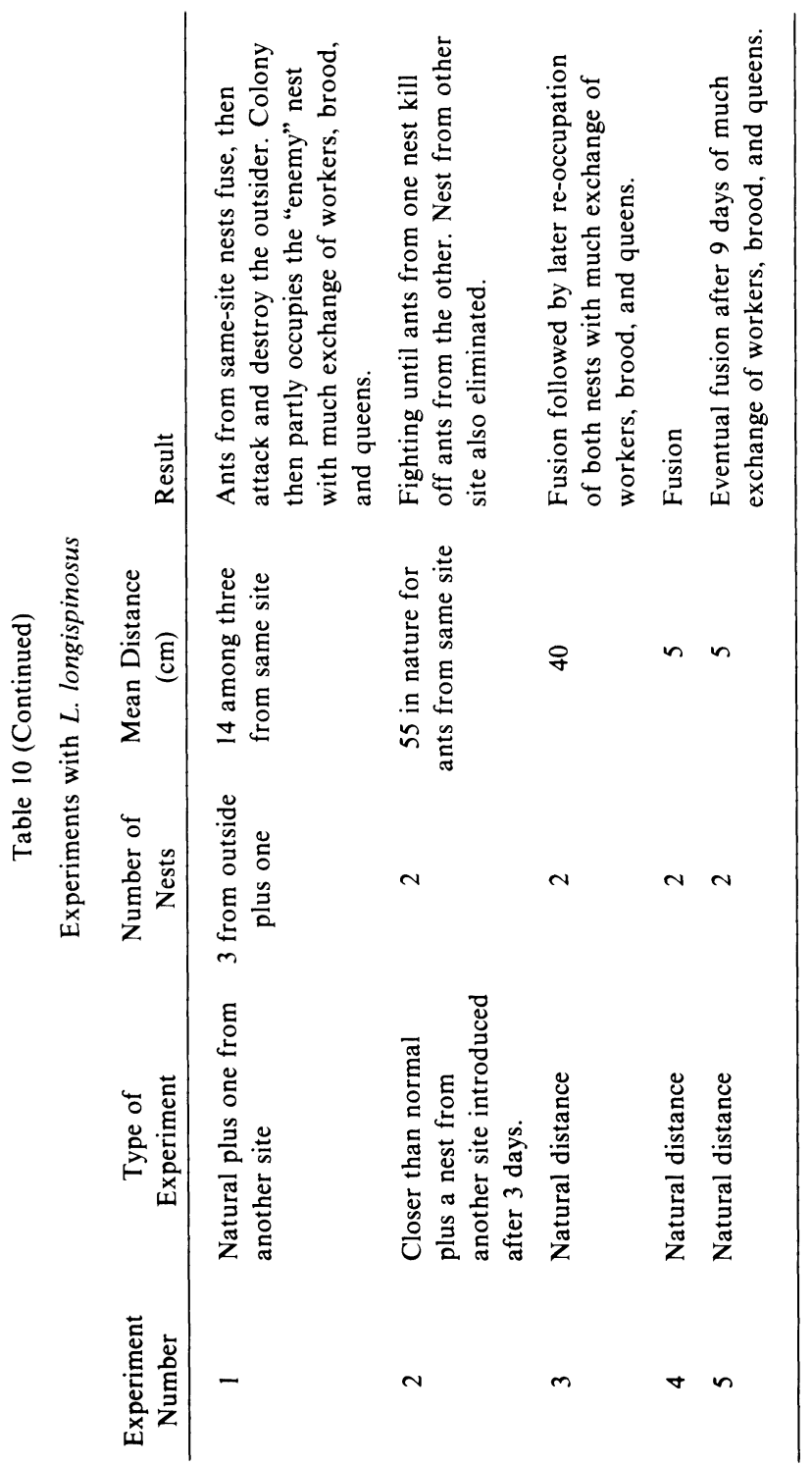


number of possible "colony odors". Ants from colonies with different odors fight, but ants from colonies with sufficiently similar odors do not fight and may merge (for a discussion, see Holldobler and Wilson, 1977).

Finally, although some data indicate that polydomy occurs in $L$. ambiguus and L. longispinosus, other data indicate that monodomy also occurs. As already noted, many apparently polydomous colonies became monodomous in the laboratory. Similar fusions may occur in nature. In addition, several experiments suggested interactions either between a polydomous and a monodomous colony or between two or more monodomous colonies. There were several instances in which the ants from two or more nests merged and then attacked the ants from another single nest. These results suggest that the ants which merged had comprised a polydomous colony and that the ants which were attacked belonged to another colony. Finally, the results of L. ambiguus experiments 25 and 26 suggested interactions among three monodomous colonies; and those of experiments 27 and 28 suggested interactions between two monodomous colonies.

\section{Discussion}

The evolutionary significance of polydomy and the question of what proportion of the queenless nests producing broods containing female pupae can be accounted for by polydomy will be discussed below. Here we simply note that some of the queenless nests of $L$. ambiguus and L. longispinosus which produce broods containing female pupae are almost surely parts of larger polydomous colonies in which there happened to be no queen at the time of collection. In the absence of data, it would be premature to conclude that polydomy occurs in L. curvispinosus. However, queenless nests are common in L. curvispinosus; and this fact and the many other similarities between L. curvispinosus on the one hand and L. ambiguus and $L$. longispinosus on the other suggest that L. curvispinosus is also facultatively polydomous.

\section{Colony Foundation}

One sign of an incipient ant colony is a nest containing one or more queens, an immature brood, and no workers. Such apparently incipient colonies of L. ambiguus, L. curvispinosus, and L. longi- 
spinosus are not easy to find. Under oak and hickory trees where there have been abundant nut falls, most inhabited nuts are occupied by more mature colonies. However, over several years, we discovered several apparently incipient colonies of L. ambiguus and L. longispinosus.

Materials and Methods

We searched for incipient colonies of $L$. ambiguus and $L$. longispinosus in late summer and early autumn. An incipient colony was defined as a nest containing one or more dealate queens with a brood, but no workers.

Results

A total of 15 apparently incipient nests was found, 8 of L. ambiguus and 7 of L. longispinosus. Table 11 lists the number of queens and the type of brood present when the nests were collected.

We tried to culture incipient colonies in the laboratory. However, perhaps because the artificial nests lacked a source of moisture, we had little success. Although the queens (perhaps unnaturally) foraged for food and water, their broods gradually languished and died. Only L. ambiguus nest 7 and L. longispinosus nest 5 produced workers in the laboratory.

Table 11 shows that the number of queens in apparently incipient nests of $L$. ambiguus ranged from 2 to 10 ; and the number of queens in apparently incipient nests of $L$. longispinosus ranged from 1 to 15. These data indicate that queens of $L$. longispinosus found new colonies on a facultatively polygynous basis. So far we have failed to find an instance of apparently monogynous colony foundation in $L$. ambiguus. However, it would be premature to conclude that polygynous colony foundation in L. ambiguus is obligatory.

Since we were mainly interested in the behavior of colonyfounding queens, we did not dissect the foundresses to determine their reproductive status. However, the presence of male pupae in $L$. ambiguus nests 4 and 8 suggests that one or more of the queens may have become fertile without insemination.

Multiple colony foundresses showed no hostility toward one another. To the contrary, apparently "cooperative" acts were common. All brood was kept in a single pile and seemed to be tended jointly. Mutual grooming was frequent; and queens often regurgitated to one another upon returning from foraging trips. Some groups of queens "took turns" foraging. 
Table 11. Apparently Incipient Colonies of L. ambiguus and L. longispinosus

\begin{tabular}{|c|c|c|}
\hline \multicolumn{3}{|c|}{ Incipient Colonies of L. ambiguus } \\
\hline Colony No. & Number of $q$ 우 & Brood When Collected \\
\hline 1 & 5 & eggs and larvae \\
\hline 2 & 3 & eggs and larvae \\
\hline 3 & 2 & eggs, larvae, pupae \\
\hline 4 & 10 & eggs, larvae, pupae \\
\hline 5 & 2 & larvae \\
\hline 6 & 2 & eggs and larvae \\
\hline 7 & 4 & eggs and larvae \\
\hline 8 & 4 & eggs, larvae and pupae \\
\hline
\end{tabular}

Incipient Colonies of L. longispinosus

\begin{tabular}{ccll} 
Colony No. & Number of $q 9$ & & Brood When Collected \\
1 & 1 & & Nil \\
2 & 1 & eggs, larvae, pupae \\
3 & 1 & & Nil \\
4 & 5 & eggs and larvae \\
5 & 2 & larvae \\
6 & 1 & larvae \\
7 & 1 & eggs, larvae, pupae \\
\hline
\end{tabular}

\section{Discussion}

These data indicate that colonies of $L$. longispinosus can be founded either by a single queen (haplometrosis) or by more than one queen (pleometrosis) and that colonies of $L$. ambiguus can be founded pleometrotically. These preliminary findings indicate that the colony-foundation behavior of L. ambiguus, L. curvispinosus, and $L$. longispinosus deserves more thorough investigation. Among the questions remaining to be answered are the following:

a. Can pleometrosis in these species lead directly and smoothly to polygynous mature colonies; or is there an obligatory period of monogyny between a colony's pleometrotic beginnings and the later adoption of supernumerary queens (Holldobler \& Wilson 1977)?

b. How closely related are multiple colony foundresses? Are they always sisters? If so, how do they get together to found a new colony?

c. Is foraging for food and water a laboratory artifact; or do colony-founding queens of these species normally forage? 
Finally, although we have no direct evidence, we suppose that many colonies of these species must originate when a queenright portion of a polydomous colony becomes permanently separated from the other parts, a process known as "budding". Incipient nests containing only queens and an immature brood seem too rare to account for all colony foundation in these species.

\section{General Discussion}

We can now reconstruct the colony life histories of these species in some detail. New colonies of $L$. longispinosus can be established either by a single newly mated young queen (haplometrosis) or by two or more such individuals (pleometrosis). New colonies of $L$. ambiguus are established pleometrotically; and it seems likely that further research will establish that colonies of this species and of $L$. curvispinosus can be founded either pleometrotically or haplometrotically. Young colonies of these species probably occupy only one nest (monodomy). However, as they grow, some colonies of $L$. ambiguus and $L$. longispinosus come to occupy two or more nests (polydomy) among which there can be an exchange of workers, brood, and queens. Mature colonies of all three species containing one or more fully fertile inseminated queens also sometimes adopt additional conspecific queens. Finally, we hypothesize that new colonies can be formed as a result of the break-up of polydomous colonies into two or more autonomous units (budding).

When considering these facts, one immediately notes a large amount of behavioral variability. Although we do not yet know whether any individual queen is potentially capable of doing more than one thing, young queens as a class can either join an established colony, found a new colony alone, or found a new colony in the company of one or more other queens. Colony life cycles and demographies are also variable. A colony can apparently have one or more queens at almost any stage of its development and can occupy one or more than one nest when mature enough to produce reproductives. Such behavioral variability is unusual, and its adaptive significance is obscure. Thus, the behavioral ecology of these three species offers many opportunities for empirical and theoretical analysis.

Two problems are particularly salient. First, we have demonstrated that some queenless nests are parts of polydomous colonies; 
and we presume that others are remnants of declining colonies. However, we can neither distinguish the two kinds of nests nor determine their relative frequencies. Reference to the proportion of nests producing all-male broods is not helpful because, in some species of Leptothoracine ants, female larvae can hibernate twice before pupating (Buschinger et al. 1975). Thus, a queenless colony might continue to produce female pupae for one or two years. Further work is needed to devise a simple means of distinguishing declining colonies from the queenless nests of polydomous colonies.

Second, we would like to know how frequently these species employ the various modes of colony foundation which we have observed and postulated. Altogether, we report observations of 872 nonincipient nests of $L$. ambiguus, 342 nonincipient nests of $L$. longispinosus, and of 8 and 7 apparently incipient nests of these two species. If one assumed that the frequency of apparently incipient nests represented the frequency of incipient colonies in the population, one would have to conclude that the average lifespan of a colony is unreasonably long. Thus, we were led to propose budding as a frequent means of colony foundation. This proposal needs verification.

However, it was the degree to which L. ambiguus, L. curvispinosus, and L. longispinosus are subject to social parasitism which initially aroused our interest; and several of the behavioral processes which we have described suggest means by which social parasitism might either evolve or be maintained. Colonies of all three species sometimes adopt newly mated conspecific queens, and colonies of L. ambiguus and L. longispinosus are sometimes founded pleometrotically. Since both these forms of polygyny require the peaceful coexistence of queens and of workers which are the offspring of different queens, both forms of polygyny are factors which might render these species susceptible to social parasitism. To be accepted by a host-species colony, a parasite queen must somehow convince the host workers and perhaps the host queen or queens that she is a legitimate potential colony member. Since the queens and workers of these species naturally accept supernumerary queens, the parasite female's task is probably simplified.

Moreover, the tendency to seek adoption by existing colonies and the tendency to join pleometrotic foundress associations may represent preadaptive traits from which parasitic modes of colony founda- 
tion might have evolved in such a group of closely related species. The queens of slave-making, temporary, and inquiline parasites found new colonies by securing adoption in a host-species colony (Buschinger 1970; Wilson 1971). Although the colony-foundation behavior of such social parasites often involves an element of violence which is probably lacking from the processes by which colonies of L. ambiguus, L. curvispinosus, and L. longispinosus adopt additional conspecific queens or additional foundresses join associations (Wesson 1939; Alloway, personal observations), the tendencies to join conspecific colonies or foundress associations could form a basis from which more elaborate parasitic colony-foundation might evolve.

Finally, the kind of polydomy seen in L. ambiguus, and L. longispinosus also embodies factors which may be both preadaptive for the evolution of socially parasitic behavior and significant in rendering a species subject to social parasitism. Polydomy in these species can involve a more or less continuous exchange of workers, brood, and queens among a colony's multiple nests. Such commerce requires a worker caste which is adept in carrying brood and adults in a fashion which might be preadaptive for slave-raiding (Buschinger 1970). In this context it is noteworthy that Wilson (1975) and Alloway (1980) have shown that L. ambiguus, L. curvispinosus, and L. longispinosus sometimes behave like facultative slave-makers.

Polydomy also requires workers in one nest to accept and tend a brood from another nest even though it may carry a somewhat unfamiliar "nest odor". Yet, any tendency to care for unfamiliar brood might render a species vulnerable to social parasitism. The more ready host-species workers are to accept unfamiliar brood, the less exactly a parasite's brood need mimic that of the host.

\section{SUMMARY}

New colonies of $L$. longispinosus can be founded by a single young queen; and colonies of $L$. ambiguus and L. longispinosus can be founded by groups of two or more young queens. Mature colonies of these two species and of $L$. curvispinosus can become polygynous or enhance the degree of their pre-existing polygyny by adopting young conspecific queens. Some colonies of $L$. ambiguus and $L$. longispinosus occupy more than one nest and exchange 
workers, queens, and brood among nests (polydomy). Other colonies have only one nest (monodomy). The significance of these findings for understanding the evolutionary origin and maintenance of social parasitism is discussed.

\section{REFERENCES}

Alloway, T. M. 1979. Raiding behaviour of two species of slave-making ants, Harpagoxenus americanus (Emery) and Leptothorax duloticus Wesson (Hymenoptera: Formicidae). Animal Behaviour, 27: 202-210.

Alloway, T. M. 1980. The origins of slavery in Leptothoracine ants (Hymenoptera: Formicidae). American Naturalist, 115: 247-261.

Buschinger, A. 1967. Verbreitung und Auswirkungen von Mono- und Polygynie bei Arten der Gattung Leptothorax Mayr (Hymenoptera: Formicidae). Inaugural Dissertation, Wurzburg. $114 \mathrm{pp}$.

Buschinger, A. 1968. Mono- und Polygynie bei Arten der Gattung Leptothorax Mayr (Hymenoptera: Formicidae). Insectes Sociaux, 15: 217-226.

Buschinger, A. 1970. Neue Vorstellungen zur Evolution des Sozialparasitismus und der Dulosis bei Ameisen (Hymenoptera: Formicidae). Biologisches Zentralblatt, 88: 273-299.

Buschinger, A. 1974. Monogynie und Polygynie in Insektensozietaten. In G. H. Schmidt (Ed.), Sozialpolymorphismus bei Insekten. Wissenschaftliche Verlagsgesellschaft m.b.h., Stuttgart, 974 p.

Buschinger, A. 1975. Eine genetische Koponente im Polymorphism der dulotischen Ameise Harpagoxenus sublaevis. Naturwissenschaften, 62: 239.

BusCHINGER, A. 1978. Genetisch bedingte Entstehung geflungelter Weibchen bei der sklavenhaltenden Ameise Harpagoxenus sublaevis (Nyl.) (Hymenoptera: Formicidae). Insectes Sociaus, 25: 163-172.

Buschinger, A., AND T. M. Alloway. 1977. Population structure and polymorphism in the slave-making ant Harpagoxenus americanus (Emery) (Hymenoptera: Formicidae). Psyche, 83: 233-242.

Buschinger, A., And T. M. Alloway. 1978. Caste polymorphism in Harpagoxenus canadensis M. R. Smith (Hymenoptera: Formicidae). Insectes Sociaux, 25: $339-350$

Buschinger, A., and T. M. Alloway. 1979. Sexual behavior in the slavemaking ant, Harpagoxenus canadensis M. R. Smith, and sexual pheromone experiments with $\boldsymbol{H}$. canadensis, $H$. americanus (Emery), and $H$. sublaevis (Nylander) (Hymenoptera: Formicidae). Zeitschrift fur Tierpsychologie, 49: 113-119.

Buschinger, A., G. Frenz, \& M. Wunderlich. 1975. Untersuchgen zur Geschlechtstierproduktion der dulotischen Ameise Harpagoxenus sublaevis (Nyl.) (Hym., Formicidae). Insectes Sociaux, 22, 169-182.

Creighton, W. S. 1950. The ants of North America. Bulletin of the Museum of Comparative Zoology (Harvard), 104: 1-585. 
Ehrhardt, H. H. 1970. Die Bedeutung von Koniginnen mit steter arrhenotoker Parthenogenese fur die Mannchenerzeugung in den Staaten von Formica polyctena Foerster (Hymenoptera: Formicidae). Inaugural Dissertation, Wurzburg, $106 \mathrm{pp}$.

Headley, A. E. 1943. Population studies of two species of ants, Leptothorax longispinosus Roger and Leptothorax curvispinosus Mayr. Annals of the Entomological Society of America, 36: 743-753.

Hölldobler, B., AND E. O. Wilson. 1977. The number of queens: An important trait in ant evolution. Naturwissenschaften, 64: 8-15.

Petersen, M., And A. Buschinger. 1971. Untersuchungen zur Koloniegrundung der Pharaoameise Monomorium pharaonis (L.). Anzeiger fur Schadlingskunde und Pflanzenschutz, 44: 121-127.

Sмiтн, M. R. 1950. On the status of Leptothorax Mayr and some of its subgenera. Psyche, 57, 29-30.

TALBOT, M. 1957. Population studies of the slave-making ant Leptothorax duloticus and its slave, Leptothorax cuvispinosus. Ecology, 38: 449-456.

Wesson, L. G. 1939. Contributions to the natural history of Harpagoxenus americanus (Hymenoptera: Formicidae). Transactions of the American Entomological Society, 35: 97-122.

Wesson, L. G. 1940. Observations on Leptothorax duloticus. Bulletin of the Brooklyn Entomological Society, 35: 73-83.

Wilson, E. O. 1971. The Insect Societies. Belknap Press of Harvard University Press, Cambridge. $X+548$ pp.

WiLson, E. O. 1974a. Aversive behavior and competition within colonies of the ant Leptothorax curvispinosus. Annals of the Entomological Society of America, 67: 777-780.

WiLson, E. O. 1974b. The population consequences of polygyny in the ant Leptothorax curvispinosus. Annals of the Entomological Society of America, 67: 781-786.

WILSON, E. O. 1975. Leptothorax duloticus and the beginnings of slavery in ants. Evolution, 29: 108-119. 

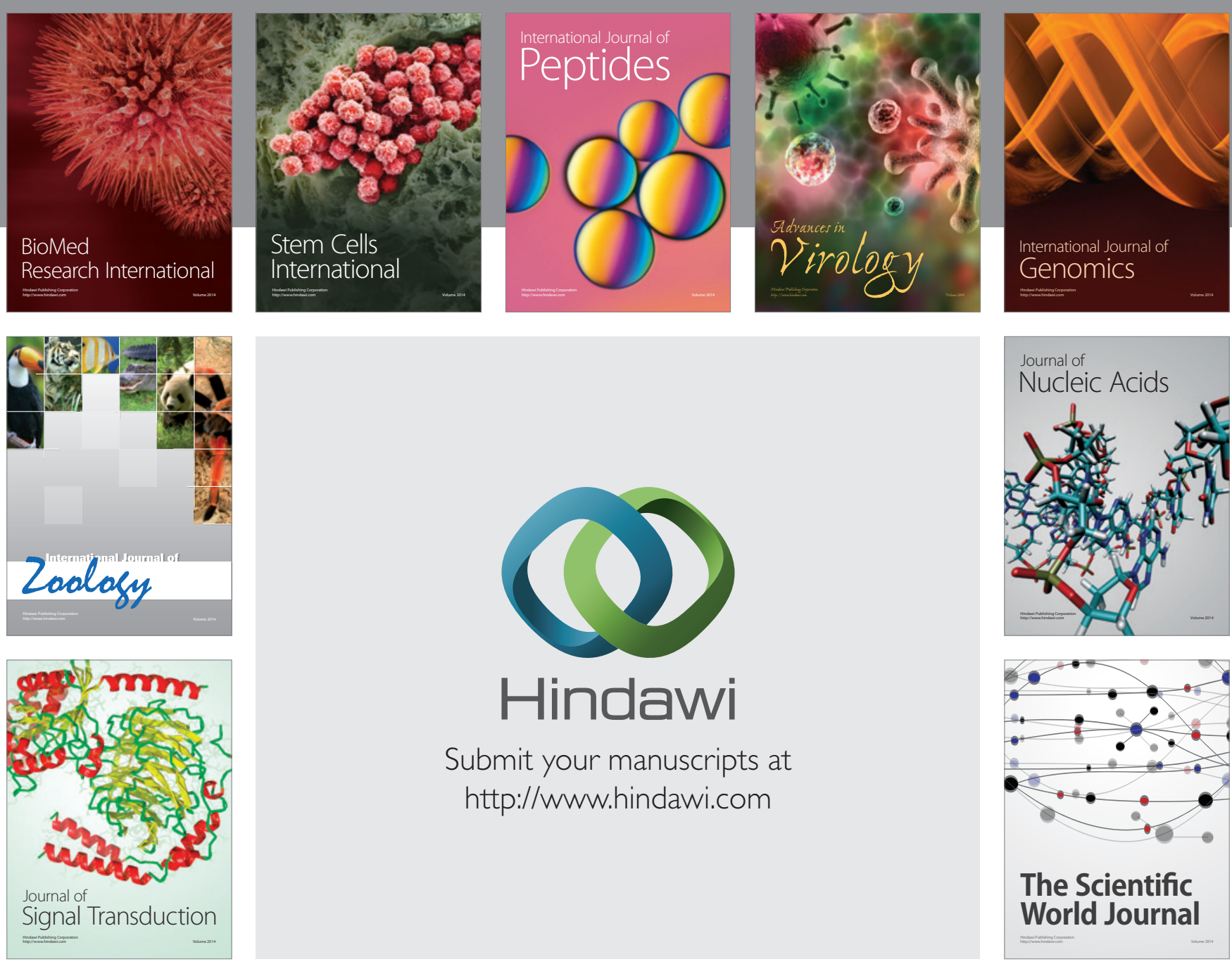

Submit your manuscripts at

http://www.hindawi.com
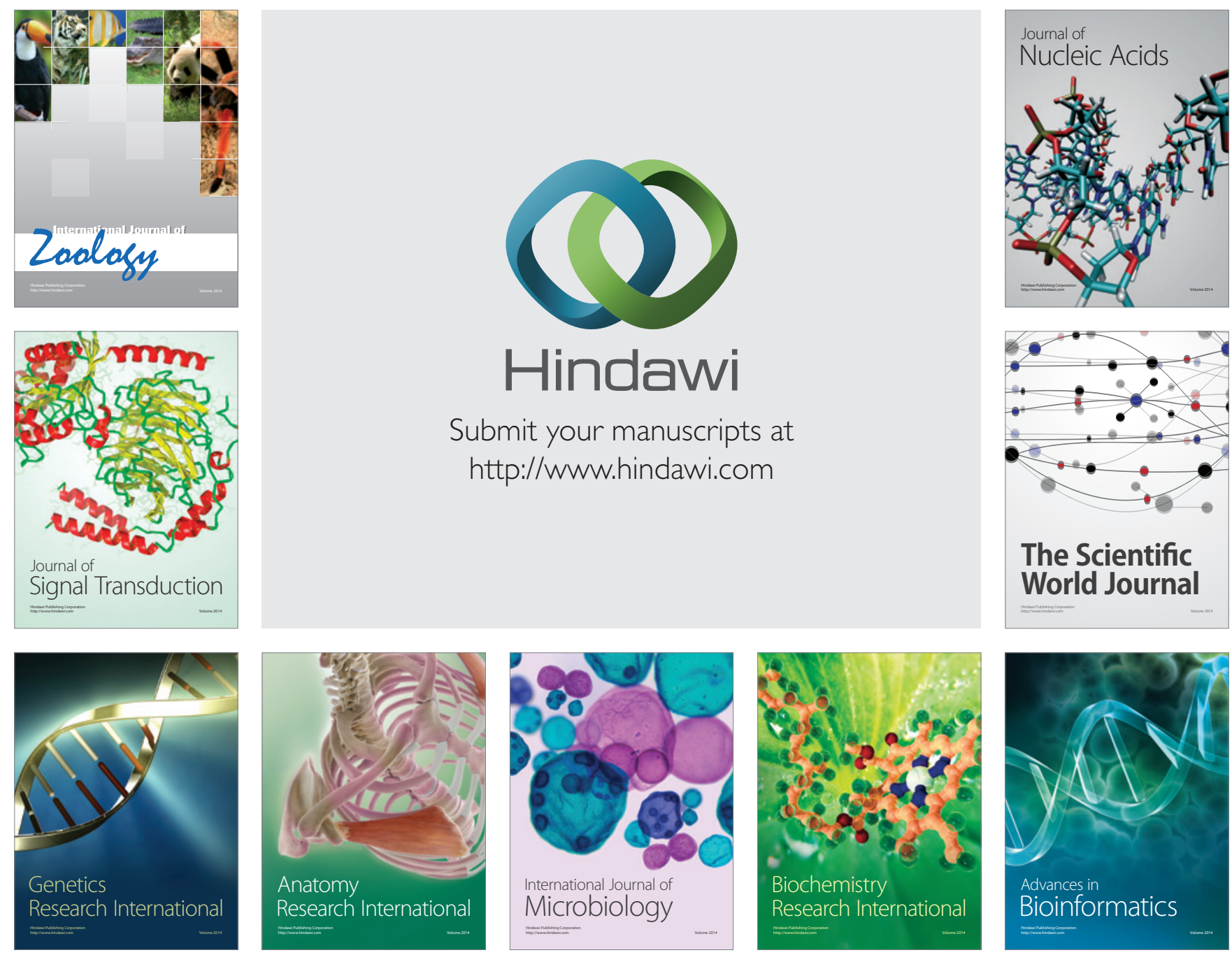

The Scientific World Journal
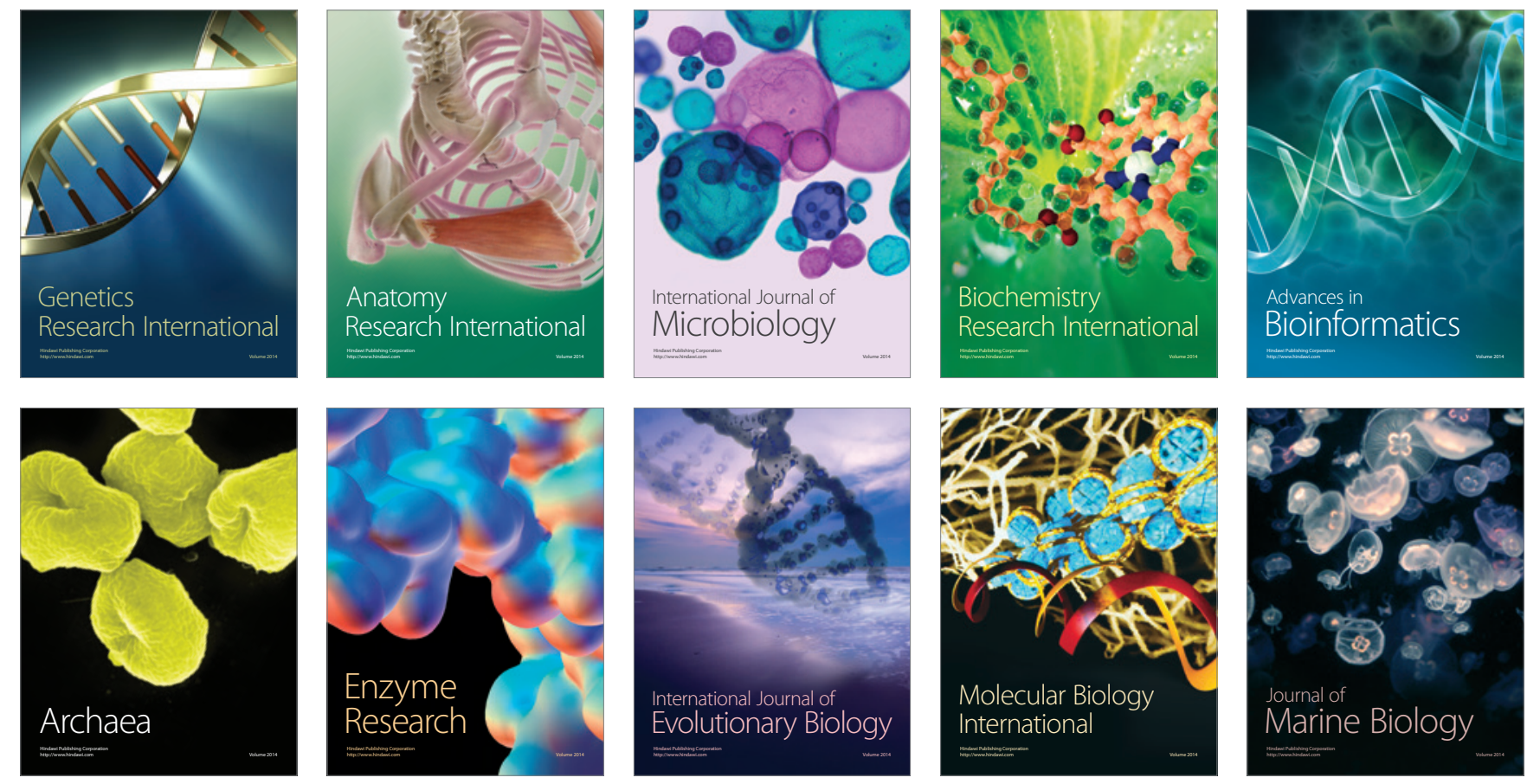